\title{
Treatment of High Salinity Wastewater Rich in Nitrate and Phosphate Using Sequential Bioreactors System
}

\author{
S. B. Al-Shammari and A. Shahalam
}

\begin{abstract}
Kuwait has built and operated an advanced wastewater treatment plant with present capacity of $\mathbf{5 0 0 , 0 0 0}$ $\mathrm{m} 3 / \mathrm{d}$. This plant providing treatment beyond tertiary utilizes the process of ultra filtration (UF) and reverse osmosis (RO). The reject water of this unit contains high concentration of total nitrogen and total phosphate. Safe disposal of this water into the environment or possible reuse needs substantial reduction of these chemicals. In this study, a bench scale sequential bioreactors system was investigated to treat a synthetic saline wastewater rich in nitrogen and phosphorus compounds. The system operated with an average hydraulic-detention time (HRT) of $24 \mathrm{~h}$ whereas, Sludge age varied within the range of 13 to 16.5 d. The results show that the average removal efficiency of the system for chemical oxygen demand (COD) was $81.3 \%$. The phosphate and nitrogen average removal were found to be $\mathbf{4 9 . 6 \%}$ and $59.7 \%$ respectively.
\end{abstract}

Index Terms-Wastewater, treatment, saline, nitrate, phosphate.

\section{INTRODUCTION}

The scarcity of water is considered as an extremely important issue to Kuwait which belongs and located in arid zones. These regions are characterized by limited rainfall, absence of fresh surface water, and limited renewable groundwater resources. During recent years economic development, high population growth, expanded urbanization and agricultural activities have placed substantial strains on the available water resources in Kuwait. The increasing imbalance between water supply and demand has compelled Kuwait to augment supplies trough seawater desalination, and reuse of treated wastewater.

To achieve this goal, a pioneering advanced treatment plant with a capacity of $500,000 \mathrm{~m}^{3} / \mathrm{d}$ had been built and commissioned in 2004 at Sulaibiya site. The plant utilizes conventional biological processes for treating wastewater up to tertiary level. The tertiary effluent is further treated through advanced processes of ultrafiltration (UF) and reverse osmosis (RO) to produce effluent with excellent quality. The ultimate goal is to recover nearly $85 \%$ of influent wastewater as effluent/product water. The remaining portion is expected to be the reject of RO systems. It constitutes a substantial portion of the total influent. These quantities of rejected wastewater have a negative impact on receiving water and

Manuscript received September 6, 2015; revised December 29, 2015.

S. B. Al-Shammari is with Environmental Health Departments, College of Health Science, The Public Authority for Applied Education and Training Kuwait (e-mail: sb.alshemmari@paaet.edu.kw, s.b.alwan@gmail.com, salalwan@gmail.com)

A. Shahalam is with a Private Consultant, Kuwait (e-mail: aashah_1942@hotmail.com). cause marine pollution. This is because salts, nitrogen and phosphorus contents are concentrated as a result of selective separation of RO membrane. The disposal or reuse of untreated RO reject wastewater has raised environmental concern. Direct disposal to water body may invigorate the growth of aquatic mass causing environmental problem. Disposing on land has potential of concentrating salts and nutrient compounds in soil and contaminating groundwater. Hence, the RO reject water produced from the wastewater treatment needs some kind of further treatment for removing concentrated organics, particularly nutrients of $\mathrm{N}$ and $\mathrm{P}$ before safe disposal or reuse.

Biological activities in the activated sludge system are sensitive to environmental factors such as temperature, $\mathrm{pH}$, dissolved oxygen and feed conductivity. The effect of salt on nitrification/denitrification process is a major concern in recent years. Saline wastewater are usually treated through physico-chemical means, as conventional biological treatment is known to be strongly inhibited by salt (mainly $\mathrm{NaCl}$ ). However, physicochemical techniques are energy-consuming and their startup and running costs are high. Nowadays, alternative systems for the removal of organic matter are studied, most of them involving anaerobic or aerobic biological treatment [1]. Previous studies indicated that high salinity adversely effects the reduction of chemical oxygen demand (COD) in normal wastewater plants of activated sludge [2], [3]. However, the adaptation of biomass to saline wastewater improved COD reduction [4], [5]. Another study indicated that nitrogen reduction is insignificantly effected up to a salt level of $4000 \mathrm{mg} / \mathrm{l}$ just little above $10 \%$ of salt concentration in normal seawater. Even at this low level of salt however, phosphorus reduction dropped from normal reduction of $82 \%$ to only $25 \%$ showing severe interference of salt [6]. Concerning nitrogen, a similar study reported that in low salt concentration, ammonia reduction can be achieved within the range of 20 to $50 \%$ [7]. Past records of studies with highly saline wastewater from seafood industry and RO or other membrane processes treating wastewater effluent are inadequate to draw any conclusive inference on the treat-ability of saline wastewater. In such water, high levels of nutrients (nitrogen ranging of $50-60 \mathrm{mg} / \mathrm{L}$ and phosphorus ranging $10-12 \mathrm{mg} / \mathrm{L}$ ) are common features. A recent sequential batch reactor (SBR) study concentrated on nutrient reduction from saline wastewater (artificial seafood processing wastewater). The wastewater was prepared to have the approximate concentrations of total COD $1000 \mathrm{mg} / \mathrm{L}$, soluble COD $500 \mathrm{mg} / \mathrm{L}$, TKN $120 \mathrm{mg} / \mathrm{L}$, PO-P $20 \mathrm{mg} / \mathrm{l}$ [8]. In this study $80-92 \%$ organics and nitrogen reduction was reported and also found that after the influent was modified with acetate addition, satisfactory phosphorus 
reduction was also achieved within 2-3 d [8]. The author reported nutrient reduction efficiency in sequential bio-reactors with variable hydraulic retention time. Best removal rate was recorded at $24 \mathrm{~h}$ hydraulic retention and 12 days sludge age. The author reported that better result is accomplished from the acclimatization of bacteria at higher salinity as reported by others [4], [5].

\section{Methodology}

\section{A. Materials and Experimental Facilities}

Experiments were conducted with a bench-scale bioreactors system with an anoxic compartment before and after the aerobic compartment and with typical recycle lines as shown in Fig. 1. The system was made of Plexiglass and had a total operating volume of 37.8 liters (equal volume of 7.51 for the anoxic and aerobic compartments). The dimensions of the reactors were $14 \mathrm{~cm}$ wide by $27 \mathrm{~cm}$ long and $20 \mathrm{~cm}$ deep. Air was introduced using filtered in-house compressed air via air diffusers placed at the bottom of the aerobic compartment for microbial metabolism. To create the anoxic compartment, a portion of the volume of the anoxic compartments was mixed gently from the top using a variable speed mixer. The system appeared to be suitable for biological treatment and successful nitrification/denitrification with removal of phosphate $\left(\mathrm{PO}_{4}\right)$ in usual domestic wastewater [9], [10]. It is a biological system with multiple aerators in series.

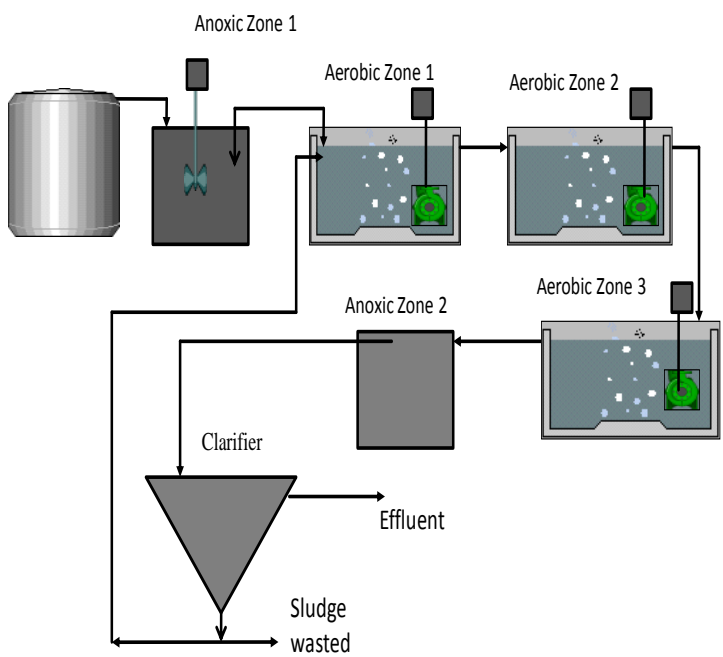

Fig. 1. Schematic diagram of the sequential bioreactors system.

\section{B. Synthetic Wastewater}

The synthetic wastewater was prepared to simulate the reverse osmosis brine produced at Sulaibiya Wastewater Treatment Plant. The required concentrations of nitrate and phosphate in synthetic wastewater were obtained by utilizing $\mathrm{NaNO}_{3}$ and $\mathrm{KH}_{2} \mathrm{PO}_{4}$, respectively. Carbon sources of methanol, acetate or glucose was added to maintain biological activity needed to degrade various concentrations of nitrate and phosphate [10], [11]. In order to achieve the required amount of salinity to resemble $\mathrm{RO}$ reject water, $\mathrm{NaCl}$ was added. The compositions of the synthetic wastewater and actual RO reject wastewater from Sulabiya wastewater plant are presented in Table I.
TABLE I: AVERAGE QUALITY PARAMETERS OF RO REJECT WASTEWATER FROM SULAIBIYA TREATMENT PLANT AND INFLOW SYNTHETIC SALINE WASTEWATER

\begin{tabular}{|c|c|c|}
\hline & $\begin{array}{c}\text { Rejected RO wastewater from } \\
\text { Sulaibiya treatment plant }\end{array}$ & $\begin{array}{c}\text { Synthetic saline } \\
\text { wastewater }\end{array}$ \\
\hline $\mathrm{T}\left({ }^{\circ} \mathrm{C}\right)$ & 22.4 & 22.3 \\
\hline $\begin{array}{c}\text { E.c. } \\
(\mu \mathrm{s} / \mathrm{cm})\end{array}$ & 6200 & 6150 \\
\hline $\mathrm{pH}$ & 7.3 & 7.5 \\
\hline $\begin{array}{l}\text { COD } \\
(\mathrm{mg} / \mathrm{l})\end{array}$ & 445 & 606 \\
\hline $\begin{array}{l}\text { BOD } \\
(\mathrm{mg} / \mathrm{l})\end{array}$ & 261 & 238 \\
\hline $\begin{array}{c}\mathrm{N}_{-} \mathrm{NO}_{3}{ }^{-} \\
(\mathrm{mg} / \mathrm{l})\end{array}$ & 24.3 & 23.2 \\
\hline $\mathrm{TN}(\mathrm{mg} / \mathrm{l})$ & 52.6 & 57.5 \\
\hline $\begin{array}{l}\mathrm{P}-\mathrm{PO}_{4}^{-} \\
(\mathrm{mg} / \mathrm{l})\end{array}$ & 75.1 & 73.5 \\
\hline
\end{tabular}

$\mathrm{Ec}=$ Electrical conductivity; $\mathrm{TN}=$ Total nitrogen $; \mathrm{BOD}=$ Biological oxygen demand $\mathrm{COD}=$ Chemical oxygen demand

\section{Process Operation}

Twenty six steady state runs based on quality were recorded. Average hydraulic-detention time in the total system (combined aerobic and anoxic) was $24 \mathrm{~h}$. Sludge wastage was performed daily by discarding sludge from the bottom of the clarifier. Wastage solid mass was calculated on the basis of average solid-mass in all tanks with targeted average sludge-age of $15 \mathrm{~d}$. Sludge age varied within the range of 13 to $16.5 \mathrm{~d}$. Average inflow rate in the system was $1.56 \mathrm{l} / \mathrm{h}$ while average return sludge flow was $1.5 \mathrm{l} / \mathrm{h}$. First tank receiving inflow and return sludge was mixed very gently to add to floc formation in the absence of any air supply. The oxygen level in this tank remained around $1 \mathrm{mg} / \mathrm{l}$. The last tank was maintained at anoxic conditions and its contents received constant gentle mixing to keep the solids suspended. The oxygen level in the fifth tank mostly remained below 1 $\mathrm{mg} / \mathrm{l}$. Oxygen level in the three aerated tanks was maintained at an average of $2.5 \mathrm{mg} / \mathrm{l}$. The water temperature and $\mathrm{pH}$ were within the range of 22 to $23^{\circ} \mathrm{C}$ and 6.3 to 8.7 , respectively.

\section{Analytical Method}

For each recirculation configuration, the reactor was operated until steady state conditions were achieved. Steady state conditions were assumed to be achieved when the most recent three measurements of chemical oxygen demand (COD) and nutrient (nitrogen and phosphorus) concentrations were within $10 \%$. Laboratory tests for water quality parameters were conducted in the laboratory at the Sulaibiya Wastewater Research Plant. Test results were cross-checked with results obtained at the MPW laboratory at the Data Monitoring Center (DMC). Main parameters measured were temperature, pH, TSS, VSS, settleable solids, COD, BOD, conductivity, TDS, sulphate, $\mathrm{TN}, \mathrm{PO}_{4}$, chloride, $\mathrm{NH}_{4}-\mathrm{N}$, alkalinity as $\mathrm{CaCO}_{3}$, and $\mathrm{NO}_{3}-\mathrm{N}$. laboratory analysis was performed according to Standard methods [12]. 


\section{RESULTS AND DISCUSSION}

\section{A. COD Removal from Saline Wastewater}

The influent concentration of COD was highly fluctuating and was in the range of from $260-760 \mathrm{mg} / \mathrm{l}$ with an average value of $605 \mathrm{mg} / \mathrm{l}$. whereas the average COD concentration in the effluent was $112 \mathrm{mg} / \mathrm{l}$. Fig. 2 shows the COD of influent, effluent and the percentage of COD removal. As can be seen in Fig. 2, there were significant reductions in COD values with an average removal efficiency of $83 \%$. This revealed the heterotrophic bacteria which is responsible of degrading the carbonaceous organic were rich in aerobic zone of the system. Results obtained in this study shows that the COD removal efficiency from saline wastewater is in agreement with previous studies been published [13]-[15].

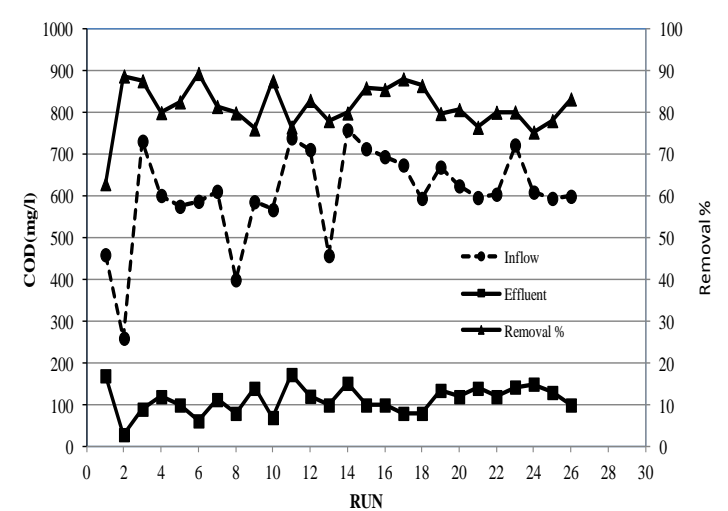

Fig. 2. Variation of influent, effluent and removal efficiency of COD.

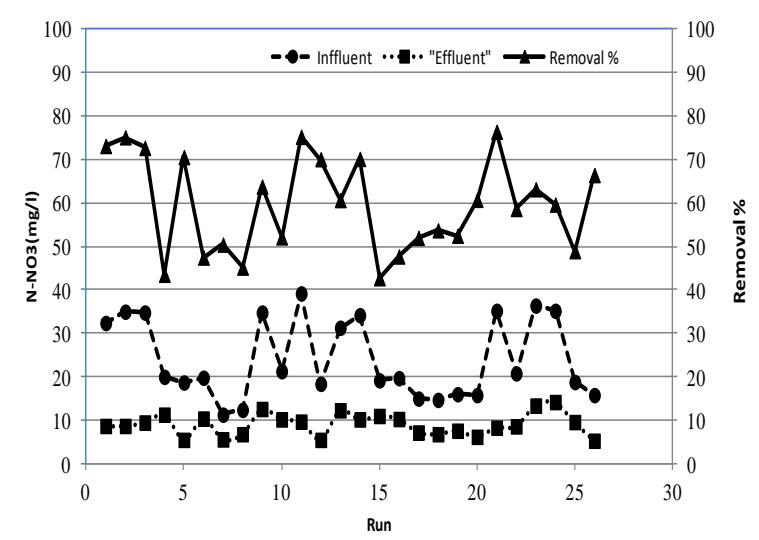

Fig. 3. Variation of influent, effluent and removal efficiency of $\mathrm{NO}_{3}$.

\section{B. Nitrogen Removal}

Nitrification is the main process in removing total nitrogen from the wastewater and this removal is occurred in two step processes: nitrification followed by denitrification. As shown in Fig. 3, nitrate concentration in this study varied between $11 \mathrm{mg} / \mathrm{l}$ to $39 \mathrm{mg} / \mathrm{l}$ and the average value was $23.1 \mathrm{mg} / \mathrm{l}$. Whereas average nitrate concentration in the effluent was 9 mg/l. Fig. 3 also presents $\mathrm{NO}_{3}{ }^{-}$removal efficiency for all steady state runs. It is noted that the percentage removal was ranged from $42.2 \%$ to $74.3 \%$ with an average value of $59.7 \%$. This average removal of nitrate indicates that the nitrification/denitrification process was incomplete. Many researchers have reported similar results and they concluded that both salinity and COD are found to be inhibitors of nitrification [16]. Furthermore, incomplete nitrogen removal in this study may be due to low concentration of mixed liquor suspended solids (MLSS) in the reactors. This occurred because of sludge circulation to the anoxic tank was started at beginning of the experiment and therefore the time for denitrifying bacteria growth was limited. The same observation is also reported by previous study [17]. Therefore more time is needed to accumulate denitrifying bacteria in the acclimatization period. In addition, poor nitrate removal might be occurred because of insufficient DO concentration $(2.5 \mathrm{mg} / \mathrm{l})$ in the aeration tank. Similar results were also observed by many researchers investigating nitrification process in wastewater treatment systems. They found that to ensure complete nitrification the DO in the aeration tank need to be maintained around $3.5 \mathrm{mg} / 1$ [18].

Fig. 4 shows the effect of inflow concentration of nitrate on its removal percentage. It is noted that at high nitrate concentration in the influent, the percentage removal of nitrate is high. This reveals that the nitrification in the aerobic zone and denitrification process in the anoxic zone was working in an acceptable manner. This observation is in good agreement with previous study [19]. In this study the authors found that the denitrification rate increased with increasing $\mathrm{N}-\mathrm{NO}_{3}$ loading.

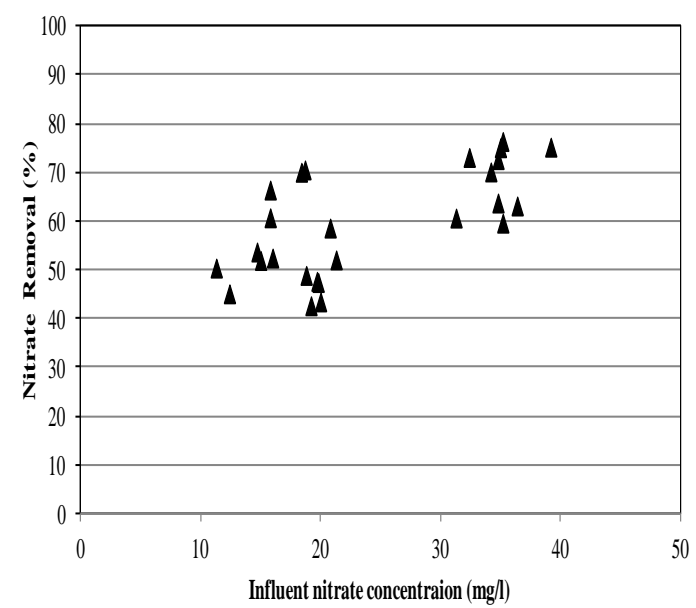

Fig. 4. Effect of influent nitrate concentration on removal efficiency of nitrate.

\section{Phosphorus Removal}

Biological $\mathrm{P}$ removal using sequential anoxic/aerobic bioreactors system was carried out in this study. In the biological phosphorus removal, the phosphorus in the influent wastewater is incorporated into cell biomass, which subsequently is removed from the process as a result of sludge wasting [19]. Fig. 5 depict the variation of P-PO4 concentration for the influent, effluent and percentage removal of phosphate occurred in the system. The influent $\mathrm{P}-\mathrm{PO} 4$ was fluctuating during the period of operation between 3 and $22 \mathrm{mg} / \mathrm{l}$ with an average value of $12.1 \mathrm{mg} / \mathrm{l}$. P-PO4 concentration in the effluent was varied from $1.3-12.3 \mathrm{mg} / \mathrm{l}$ with an average value of $6.2 \mathrm{mg} / \mathrm{l}$. Phosphate removal was ranged between 38.2 and $63.5 \%$ with an average value of $49.6 \%$. This restively poor elimination of phosphate is expected in this type of conventional processes. The incomplete phosphorus removal may resulted from carbon substrate competition between phosphorus accumulating organisms (PAOs) and the denitrifying bacteria. Excess carbon substrate in the system is crucial to successful removal 
for both nitrate and phosphate. Biological phosphorus removal is initiated in the anaerobic reactor where external carbon source is taken up by PAOs and converted to carbon storage products that provide energy and growth in the anoxic and aerobic reactors. Similar observation were reported by many researchers investigating biological nutrients removal process in wastewater treatment systems [20].

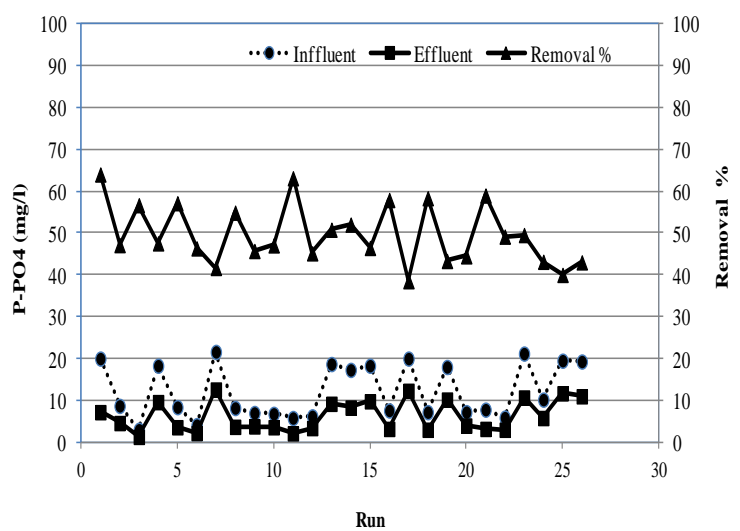

Fig. 5. Variation of influent, effluent and removal efficiency of $\mathrm{P}_{-} \mathrm{PO}_{4}$.

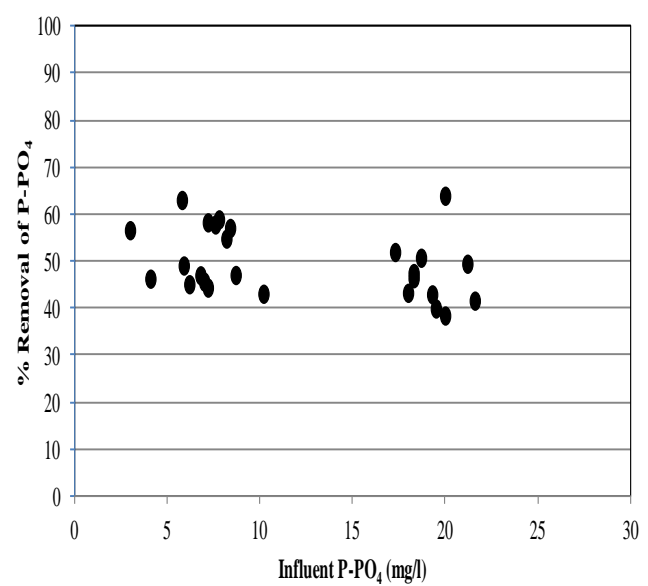

Fig. 6. Effect of influent phosphate concentration on removal efficiency of phosphate.

The effect of influent concentration of $\mathrm{P}-\mathrm{PO}_{4}$ on reduction percentage of $\mathrm{P}_{-} \mathrm{PO}_{4}$ is presented in Fig. 6. As shown in the figure and unlike $\mathrm{N}-\mathrm{NO}_{3}$, it is observed that the effect of influent concentration of $\mathrm{P}-\mathrm{PO}_{4}$ was very small on the reduction rate of $\mathrm{P}-\mathrm{PO}_{4}$. Total phosphorus removal is the difference between total phosphorous uptake and total phosphorus released. This observation indicated that the phosphorus elimination in the system was mainly achieved by microorganism synthesis taken place in the aerobic zone. Similar finding of previous researches mentioned that the phosphorus removal is mainly resulted from cell growth rather than biological phosphorus removal mechanisms of PAOs [21], [22].

\section{CONCLUSION}

In this study a laboratory-scale system was developed to biologically treat synthetic saline wastewater. The results of this study demonstrated high removal efficiency was achieved for COD with an average removal efficiency of $83 \%$. The results showed that the tested system was capable of handling impact of high organic load. The average removal efficiencies of $\mathrm{N}-\mathrm{NO}_{3}, \mathrm{P}-\mathrm{PO}_{4}$ were $59.7 \%$ and $49.6 \%$, respectively. Although the nitrogen and phosphorus removal was not very high, it could be improved by modifying operating conditions such as increasing concentration of MLSS, DO and carbon source. The system can be used for the treatment of high salinity waste water with high organic load.

\section{ACKNOWLEDGMENT}

The authors would like to thank Kuwait Foundation for advancement of Sciences and Kuwait Institute for Scientific Research for funding the study.

\section{REFERENCES}

[1] O. Lefebvre and R. Moletta, "Treatment of organic pollution in industrial saline wastewater: A literature review," Water Research, vol 40, pp. 3671-3682, 2006.

[2] A. Li and G. Guowei, "The treatment of saline wastewater using a two-stage contact oxidation method," Water Science Technology, vol. 28, pp. 31-37, 1996.

[3] F. Omil, R. J. Mendez, and J. M. Lema, "Characterization of biomass from a pilot plant digester treating saline wastewater," Journal of Chemical Technology and Biotechnology, vol. 63, pp. 384-392, 1995

[4] M. F. Hamoda and I. Alattar, "Effects of high sodium chloride concentrations on activate sludge treatment," Water Science Technology, vol. 31, pp. 61-72, 1995.

[5] F. Kargi and A. R. Dincer, "Biological treatment of saline wastewater in an aerated percolator unit utilizing halophilic bacteria," Environmental Technology, vol. 19, pp. 529-537, 1996.

[6] Z. H. Abu-Gharah and J. H. Sherrard, "Biological nutrient removal in high salinity wastewater," Journal of Environmental Science and Health A, vol. 28, pp. 599-613, 1993.

[7] S. L. Klemetson and M. E. Lang, "Treatment of saline wastewaters using a rotating biological contractor," Journal of Water Pollution Control Federation, vol. 56, pp. 1254-1259, 1984.

[8] N. Intrasungkha, J. Keller, and L. Blackall, "Biological nutrient removal efficiency in treatment of saline wastewater," Journal of Water Science and Technology, vol. 39, pp. 180-190, 1999.

[9] O. Nowak, V. Kuhn, and V. Muller, "A comparison of different concepts of the running-in of nitrification and denitrification in activated sludge plants," Wat. Sci. Tech., vol. 39, no. 6, pp. 53-60, 1999.

[10] I. M. Sudiana, "Metabolism of enhanced biological phosphorus removal and nonenhanced biological phosphorus removal sludge with acetate and glucose as carbon source," J. Wat. Sci. Technology, vol. 39, no. 6, pp. 29-35, 1999.

[11] N. Intrasungkha, J. Keller, and L. Blackall, "Biological nutrient removal efficiency in treatment of saline wastewater," J. Wat. Sci. Technology, vol. 39, no. 6, pp. 180-190, 1999.

[12] APHA, AWWA and WEF, Standard Methods for Examination of Water and Wastewater, American Public Health Association, American Water Works Association and Water Environment Federation, USA, 2005.

[13] F. Kargi and A. Uygur, "Improved nutrient removal from saline wastewater in an SBR by halobacter supplemented activated sludge," Env. Eng. Sci, vol. 22, no. 2, pp. 170-176, 2005.

[14] A. Azhdarpoor, P. Mohammadi, and M. Dehghani, "Removal of phosphate from municipal wastewater using anaerobic / aerobic modified SBR reactor," International Journal of Environmental Science and Toxicology, vol. 2, no. 8, pp. 152-159, 2014.

[15] Z. Fu, F. Yang, Y. An, and Y. Xue, "Simultaneous nitrification and denitrification coupled with phosphorus removal in an modified anoxic/oxic-membrane bioreactor (A/O-MBR)," Biochemical Engineering Journal, vol. 43, no. 2, pp. 191-196, 2009

[16] A. F. Ramos, M. A. Gomez, E. Hontoria, and J. G. Lopez, "Biological nitrogen and phenol removal from saline industrial wastewater by submerged fixed-film reactor," Journal of Hazardous Material, vol 142, pp. 175-183, 2007.

[17] A. H. Birima, M. J. Noor, T. A. Mohammed, S. A. Muyibi, and A. Idris, "Simultaneous organic and nitrogen removal using anoxic-aerobic membrane bioreactor," International Journal of Engineering and Technology, vol. 2, no. 2, pp. 36-42, 2005.

[18] B. Rajesh, J. Uan, I. Chung, S. Kaliappan, and I. Yeom, “A study on the performance of a pilot scale A2/0-MBR system in treating domestic 
wastewater," Journal of Environmental Biology, vol. 30, no. 6, pp. 959-963, 2009.

[19] M. Kermani, B. Bina, H. Movahedian, M. Amin, and M. Nikaeen, "Biological phosphorus and nitrogen removal from wastewater using moving bed biofilm process," Iranian Journal of Biotechnology, vol. 7, no. 1, pp. 19-27, 2009

[20] G. Tchobanoglous, F. Burton, and H. Stensel, Wastewater Engineering: Treatment and Reuse, 4th Eds., McGraw Hill, New York, 2003.

[21] K. Ahna, K. Song, and E. Cho. "Enhanced biological phosphorus and nitrogen removal using a sequencing anoxicknaerobic membrane bioreactor (SAM) process," Desalination, vol. 157, pp. 345-352, 2003.

[22] L. Zhidong, Z. Yong, X. Xincheng, Z. Lige, and Q. Dandan, "Study on anaerobic/aerobic membrane bioreactor treatment for domestic wastewater," Polish J. of Environ. Stud, vol. 18, no. 5, pp. 957-963, 2009.

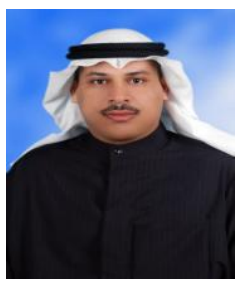

Saud B. Al-Shammari was born in State of Kuwait. In 2002 he received his $\mathrm{PhD}$ degree in chemical engineering from Manchester University, UK. After graduation, he was a scientific researcher at Water Technologies Department in Kuwait Institute for Scientific Research (KISR). Since 2010 to now, he has been professor associate at Environmental Health Department in public authority for applied education and training. His research interests include water and wastewater treatment, environmental engineering and seawater desalination. He has published more than 25 scientific articles which were published in international journals.

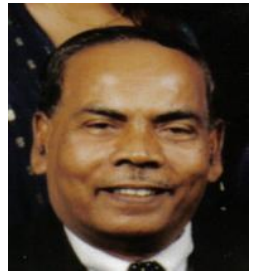

Abulbasher Shahalm was born in Bangladesh in 1942. In 1975 he received his PhD degree in civil engineering from University of Toledo, USA. His major fields of interest span environmental engineering with specific research work undertaken in biological treatment of wastewater, and pollutant migration through soil and ground water. He reckons 40 years' teaching and research experience in civil and environmental engineering. He also has more than 80 journal publications. He is currently a private consultant. 